\title{
Bahan Pakan Sapi Potong di Kelompok Tani Ternak Sapi Potong Putra Nusa Desa Kondangjajar Kecamatan Cijulang Pangandaran
}

\section{Beef Cattle Feedsstufs in The Putra Nusa Beef Cattle Farmer Group Kondangjajar Village Cijulang SubdistrictPangandaran}

Tidi Dhalika ${ }^{1}$, U. Hidayat Tanuwiria ${ }^{1}$, Budi Ayuningsih ${ }^{1}$, Atun Budiman ${ }^{1}, \operatorname{Iman}_{\text {Hernaman }}{ }^{1}$, Rahmat Hidayat $^{1}$, Tutiyana $^{1}$, Salman Parisi ${ }^{1}$

\section{* Korespondensi Penulis:}

\section{Tidi Dhalika}

E-mail: tidi.dhalika@unpad.ac.id

${ }^{1}$ Laboratorium Nutrisi Ternak Ruminan dan Kimia Makanan Ternak, Fakultas Peternakan, Universitas Padjadjaran, Sumedang

Submitted Jan 25, 2021.

Revised Jan 28, 2021.

Accepted Jan 31, 2021.

\begin{abstract}
Provision of feedstuffs for ration making is an important aspect in the beef cattle production system. Feedstuffs that can be used for beef cattle rations, including grass and legumes as the main feed and concentrate feed in a mixture of energy sources such as rice bran, corn, sorghum and cassava, protein sources in the form of coconut and palm oil cake, sources of vitamins and minerals as supplementary feed. Community Service Activities aim to improve the knowledge and skills of farmers in the use of local feedstuffs for beef cattle rations in the Putra Nusa Beef Cattle Farmer Group, Kondangjajar Village, Cijulang Pangandaran. The results show that the knowledge of members of the Putra Nusa Livestock Farmers Group regarding feedstuffs for beef cattle increase, this change in knowledge encourages group members' interest in developing beef cattle, even higher. Community service like this needs to be carried out continuously at the same location with wider material for a certain period of time as a form of planned assistance to group members so that the innovation adoption process can take place in accordance with the dynamics of knowledge development and the needs of beef cattle business carried out by group members.
\end{abstract}

Keywords: Feedstuffs, beff cattle, and farmer group

\begin{abstract}
Abstrak
Penyediaan bahan pakan untuk pembuatan ransum merupakan aspek penting dalam sistem produksi sapi potong. Bahan pakan yang dapat dimanfaatkan untuk ransum sapi potong, diantaranya adalah rumput dan legume sebagai pakan utamanya serta pakan konsentrat berupa campuran bahan pakan sumber energi seperti dedak padi, jagung, sorgum dan umbi singkong, sumber protein berupa bungkil kelapa dan sawit, sumber vitamin dan mineral serta pakan imbuhan. Kegiatan Pengabdian Kepada Masyarakat bertujuan meningkatkan pengetahuan dan keterampilan peternak dalam pemanfaatan bahan pakan lokal untuk ransum sapi potong di Kelompok Tani Ternak Sapi Potong Putra Nusa Desa Kondangjajar Kecamatan Cijulang Pangandaran. Hasil kegiatan menunjukkan bahwa pengetahuan anggota Kelompok Tani Ternak Putra Nusa mengenai bahan pakan untuk sapi potong telah mengalami peningkatan, perubahan pengetahuan ini mendorong minat anggota kelompok untuk mengembangkan sapi potong, semakin tinggi. Pengabdian kepada masyarakat seperti ini perlu dilakukan secara berkesinambungan pada lokasi yang sama dengan materi yang lebih luas sampai periode waktu tertentu sebagai bentuk pendampingan terencana terhadap anggota kelompok agar proses adopsi inovasi dapat berlangsung sesuai dinamika perkembangan pengetahuan dan kebutuhan usaha sapi potong yang dilakukan anggota kelompok tersebut.
\end{abstract}

Kata Kunci: Bahan pakan, sapi potong, dan kelompok tani ternak. 


\section{Pendahuluan}

Kabupaten Pangandaran adalah salah satu kabupaten di Provinsi Jawa Barat sebagai hasil pemekaran wilayah administratif dari Kabupaten Ciamis, penetapannya didasarkan kepada Undang Undang Nomor 21 Tahun 2012, dengan letak ibukota kabupaten berada di Kecamatan Parigi. Batas wilayah administratif Kabupaten Pangandaran adalah Kabupaten Ciamis dan Kota Banjar di bagian utara, Kabupaten Cilacap di bagian timur dan Samudra Hindia di bagian selatan, serta Kabupaten Tasikmalaya di bagian barat. Luas wilayah adminsitratif Kabupaten Pangandaran adalah 1.680 $\mathrm{km}^{2}$ dengan titik wilayah terendah 0,00 meter dari permukaan laut. Wilayah administratif Kabupaten Pangandaran meliputi sepuluh kecamatan, yaitu Kecamatan Cigugur, Cijulang, Cimerak, Kalipucang, Langkaplancar, Mangunjaya, Padaherang, Pangandaran, Parigi dan Sidamulih, kesepuluh kecamatan tersebut meliputi 93 desa. Jumlah total penduduk Kabupaten Pangandaran berdasarkan data Tahun 2014 adalah 450.658 orang dengan kepadatan penduduk sebesar 270 orang $/ \mathrm{km}^{2}$.

Kecamatan Cijulang sebagai salah satu wilayah adminsitratif Kabupaten Pangandaran memiliki wilayah administratif desa sebanyak tujuh, yaitu Desa Batukaras, Ciakar, Cibanten, Cijulang, Kertayasa, Margacinta dan Kondangjajar. Kegiatan ekonomi sebagian besar masyarakat Desa Kondangjajar adalah pertanian, peternakan dan perikanan, diantaranya pemeliharaan sapi potong, salah satunya adalah masyarakat petani yang tergabung dalam Kelompok Tani Ternak Sapi Potong Putra Nusa yang melakukan kegiatan pertanian dalam bentuk (1) usaha pembibitan sapi potong Peranakan Ongole (PO), Persilangan Sapi Lokal dengan Limousin dan Simental serta (2) penyewaan alat bajak sawah (traktor).

Lahan untuk kegiatan usaha pembibitan sapi potong adalah sekitar 2 (dua) hektar, merupakan lahan kekayaan Desa Kondangjajar, digunakan oleh Kelompok Tani Ternak Sapi Potong Putra Nusa untuk kandang kelompok sapi potong dan penanaman hijauan pakan berupa rumput dan legume. Untuk memenuhi kebutuhan ransum sapi potong yang dipelihara di Kelompok Tani Ternak Sapi Potong Putra Nusa, selain menggunakan rumput yang dibudidayakan pada lahan 2 hektar tersebut, anggota kelompok mengambil rumput lapangan yang ada di sekitarnya, baik dari lahan kering maupun lahan sawah sementara menunggu penggarapan lahan sawah selanjutnya.

Beberapa bahan pakan yang dapat dimanfaatkan untuk penyediaan ransum sapi potong, selain hijauan pakan sebagai pakan utama sapi potong, perlu ditambahkan beberapa bahan pakan lainnya sebagai sumber energi, protein, vitamin dan mineral agar produktifitas sapi potong yang dipelihara dapat ditingkatkan dari kondisi saat ini, mengingat Kabupaten Pangandaran merupakan daerah yang sedangkan dikembangkan dan pada saatnya akan membutuhkan pasokan produk ternak berupa daging sapi dalam jumlah yang lebih banyak.

Ransum merupakan salah satu faktor yang memberikan pengaruh langsung terhadap produksi sapi potong. Ketersediaan ransum yang berkesinambungan akan menjamin kuantitas dan kualitas produksi daging yang dihasilkan dalam bentuk pertambahan bobot badan yang baik, atau pertumbuhan anak yang tinggi, perubahan yang terjadi pada komposisi bahan pakan atau zat makanan dalam ransum yang diberikan akan mengakibatkan perubahan performa ternak sapi potong yang dihasilkan, untuk menghasilkan produksi anak yang baik maka pemberian ransum harus mendapat perhatian serius dari peternak sapi potong. Keberhasilan penyediaan ransum sapi potong yang baik sangat ditentukan oleh pengetahuan peternak sapi potong mengenai berbagai bahan pakan yang dapat digunakan sebagai komponen penyusun ransum, terutama bahan pakan lokal yang dapat dimanfaatkan untuk kepentingan tersebut diatas.

Maksud dan tujuan kegiatan pengabdian kepada masyarakat pada Kelompok Tani Ternak Sapi Potong Putra Nusa di Desa Kondangjajar Kecamatan Cijulang Pangandaran, diantaranya adalah meningkatkan pengetahuan peternak sapi potong mengenai bahan pakan untuk penyusunan ransum, khususnya bahan pakan lokal, meningkatkan pengetahuan peternak sapi potong mengenai kandungan zat makanan didalam bahan pakan, dan meningkatkan kemampuan peternak sapi potong dalam proses penyediaan ransum untuk sapi potong yang dipeliharanya. Manfaat yang dapat diperoleh dari kegiatan pengabdian kepada masyarakat yang dilaksanakan, diantaranya adalah peningkatan pengetahuan peternak sapi potong mengenai sumberdaya bahan pakan lokal dalam memenuhi kebutuhan ransum sepanjang tahun untuk peningkatan produksi sapi potong, peningkatan 
pengetahuan peternak sapi potong mengenai komposisi zat makanan dalam bahan pakan, sebagai informasi dasar penyusunan ransum sapi potong, dan Kelompok Tani Ternak Sapi Potong Putra Nusa yang melaksanakan kegiatan usaha ternak sapi potong dapat meningkatkan kegiatan ekonomi pedesaan, terutama pengembangan peternakan, khususnya di Desa Kondangjajar Kecamatan Cijulang Pangandaran.

Berdasarkan hal tersebut, pembekalan pengetahuan dan keterampilan peternak dalam menentukan bahan pakan yang dapat dimanfaatkan untuk penyusunan ransum sapi potong menjadi penting, dan peningkatan pengetahuan peternak mengenai bahan pakan yang dapat digunakan sebagai bahan baku pembuatan ransum sapi potong sesuai tujuan pemeliharaannya dapat dilakukan melalui kegiatan penyuluhan.

\section{Materi dan Metode Pelaksanaan}

\section{Lokasi dan Waktu Pelaksanaan}

Kelompok masyarakat sasaran dalam kegiatan pengabdian kepada masyarakat ini adalah anggota Kelompok Tani Ternak Sapi Potong Putra Nusa di Desa Kondangjajar Kecamatan Cijulang Pangandaran. Kegiatan pengabdian kepada masyarakat dilaksanakan di sekretariat kelompok yang berlokasi area perkandangan sapi potong di Dusun Kalensari RT 23 RW 05 Desa Kondangjajar Kecamatan Cijulang Pangandaran. Waktu pelaksanaan kegiatan berlangsung selama 4 (bulan) dimulai dari bulan September - Desember 2019.

\section{Kerangka Pemecahan Masalah}

Metode pelaksanaan Pengabdian Kepada Masyarakat pada anggota Kelompok Tani Ternak Sapi Potong Putra Nusa di Desa Kondangjajar Kecamatan Cijulang Pangandaran adalah pelatihan mengenai bahan pakan sapi potong yang dilaksanakan dengan metode penyuluhan melalui kegiatan ceramah dan diskusi mengenai klasifikasi bahan pakan berdasarkan sifat kimianya, meliputi bahan pakan berupa hijauan kering dan jerami, hijauan yang diberikan segar, silase, bahan pakan sumber energi, protein, mineral dan bahan imbuhan (feed additive), dihubungkan dengan ketersediaan bahan pakan berdasarkan klasifikasi bahan pakan tersebut yang dapat ditemukan di sekitar lingkungan lokasi kegiatan pengabdian kepada masyarakat.

Kerangka pemecahan masalah dalam bentuk program pelatihan dapat dilakukan melalui beberapa tahap, yaitu ; (1) pemetaan permasalahan, meliputi kegiatan identifikasi terhadap permasalahan yang ada dan diungkapkan menggunakan teknik observasi terhadap objek di daerah sasaran yang dilaksanakan sebagai tindakan analisis situasi terhadap kondisi faktual. Selanjutnya dilakukan inventarisasi terhadap potensi daerah sasaran supaya pemecahan masalah dapat dilakukan dengan memanfaatkan sumberdaya lokal menggunakan teknologi tepat guna yang dapat dikembangkan oleh masyarakat sasaran. Observasi dilakukan melalui konfirmasi dengan peternak untuk mengetahui penguasaan ilmu pengetahuan, terutama mengenai bahan pakan sapi potong, kegiatan observasi dilakukan oleh Tim Pengabdian Kepada Masyarakat bersama mahasiswa Fakultas Peternakan Universitas Padjadjaran Program Studi Diluar Kampus Utama (PSDKU) Pangandaran, hasil observasi digunakan sebagai dasar bagi penetapan materi dan bahan diskusi mengenai bahan pakan sapi potong, terutama bahan pakan lokal yang dapat dimanfaatkan sebagai komponen ransum sapi potong sesuai dengan sumberdaya lingkungan Desa Kondangjajar Kecamatan Cijulang Pangandaran, (2) penyuluhan, dilakukan melalui metode ceramah dan diskusi untuk mengungkapkan informasi dan harapan peternak sapi potong anggota kelompok. Pada kegiatan penyuluhan dilakukan Pre dan Post Test untuk mengetahui perubahan pengetahuan bahan pakan sapi potong dari peserta pelatihan, kegiatan Pre dan Post Test ini dipandu oleh mahasiswa Asisten Laboratorium Nutrisi Ternak Ruminan dan Kimia Makanan Ternak Fakultas Peternakan Universitas Padjadjaran, dan (3) pendampingan yang dilakukan untuk melakukan evaluasi terhadap pelaksanaan hasil pelatihan di tingkat anggota kelompok. Selama kegiatan pendampingan oleh Tim Pengabdian Kepada Masyarakat, dilakukan kordinasi dengan Pengurus Kelompok Tani Ternak dan mahasiswa Fakultas Peternakan Universitas Padjadjaran PSDKU Pangandaran untuk memantau pelaksanaan kegiatan peternakan sapi potong di Desa Kondangjajar Kecamatan Cijulang Pangandaran.

\section{Hasil dan Pembahasan}

\section{Kondisi Umum}

Secara umum kegiatan pengabdian kepada masyarakat yang dilaksanakan selama periode waktu antara September - Desember 2019 sudah dapat meningkatkan pengetahuan dan wawasan anggota kelompok mengenai bahan pakan sapi potong. 
Namun demikian, berdasarkan sikap, perilaku dan keterampilan teknis, belum dapat dipastikan bahwa seluruh peternak dapat menerapkannya dalam usaha pengembangan peternakan sapi potong di Desa Kondangjajar Kecamatan Cijulang Pangandaran.

Beberapa faktor yang diduga merupakan kendala bagi implementasi pemberian ransum sapi potong yang baik sesuai kebutuhan zat makanan dan tujuan pemeliharaannya, terungkap bahwa tidak cukup hanya memperhatikan aspek manajemen peternakan sapi potong saja, tetapi aspek lain menyangkut sosial dan ekonomi masyarakat perlu dijadikan bahan pertimbangan, seperti aspek pendidikan, sumber pendanaan, informasi pasar dan kedudukan sapi potong dalam sistem usaha tani yang dijalankan oleh anggota kelompok, serta kebijakan pengembangan wilayah yang dilakukan oleh pemerintah daerah.

Faktor pendukung yang menjadi landasan dalam pengembangan peternakan sapi potong di Desa Kondangjajar Kecamatan Cijulang Pangandaran, adalah (1) eksistensi Kelompok Tani Ternak Sapi Potong Putra Nusa yang relatif sudah lama melakukan kegiatan pembibitan sapi potong dan (2) dukungan pemerintah Desa Kondangjajar Kecamatan Cijulang Pangandaran dengan mengalokasikan sebagian lahan kekayaan desa seluas 2 (dua) hektar untuk lokasi kegiatan Kelompok Tani Ternak Sapi Potong Putra Nusa.

\section{Pemetaan Peternakan}

Selama proses pemetaan peternakan dalam rangka kegiatan pengabdian kepada masyarakat pada Kelompok Tani Ternak Sapi Potong Putra Nusa di Desa Kondangjajar Kecamatan Cijulang Pangandaran dapat diketahui permasalahan yang menjadi kendala bagi perkembangan kegiatan peternakan sapi potong diantaranya adalah penyediaan bahan pakan untuk menyusun ransum sapi potong, terutama ketersediaan lahan untuk budidaya hijauan pakan berupa rumput maupun legume yang semakin sempit karena alih fungsi lahan dari lahan pengangonan ke pertanian tanaman pangan, bahkan alih fungsi lahan menjadi keperluan non pertanian, seperti desakan pemukiman akibat perkembangan jumlah penduduk yang sangat tinggi.

Faktor produksi sangat penting bagi pengembangan komoditas pertanian, termasuk produksi ternak, salah satunya adalah ketersediaan lahan. Sebagai sumberdaya alam strategis bagi pembangunan, pengunaan luas tanah harus tetap dijaga untuk mempertahankan produksi (Catur, dkk.,
2010). Sementara itu, menurut Corre, dkk; (2006) alih fungsi lahan sangat cepat terjadi di Indonesia. Saputra dan Budhi (2015), menyatakan bahwa permasalahan ekonomi menjadi penyebab utama yang mengakibatkan alih fungsi lahan pertanian dilakukan. Selanjutnya dikemukakan oleh Irawan dan Friyatno (2002), bahwa penurunan atau peningkatan lahan untuk sektor primer, terutama sektor pertanian sangat dipengaruhi oleh program pembangunan dan mempertahankan lahan untuk pertanian menjadi tidak sulit jika manusia dapat mereklamasi laut (Hiroyuki et al., 2002), wilayah kabupaten Pangandaran dan sekitarnya dimungkinkan untuk upaya tersebut dalam rangka mempertahankan luas lahan pertanian.

Berdasarkan karakteristik wilayah kerja Kelompok Tani Ternak Sapi Potong Putra Nusa, terkait dengan potensi sumberdaya bahan pakan lokal yang cukup potensil, dapat diidentifikasi beberapa bahan pakan lokal yang termasuk kelompok hijauan makanan ternak, diantaranya adalah rumput raja (king grass), rumput lapangan yang terdapat pada lahan sawah sebelum lahan sawah tersebut ditanami padi, hasil samping tanaman perkebunan kelapa dan tanaman pangan lainnya, terutama tanaman serealia seperi jerami padi dan jagung.

Jerami padi dan jerami jagung merupakan bahan pakan lokal alternatif yang memiliki potensi untuk digunakan sebagai bahan pakan sumber serat kasar pada pengembangan peternakan sapi potong. Ketersediaan jerami padi dari aspek produksi massa relatif besar, namun kualitas nutrisinya sangat rendah. Menurut Hartadi dkk (1991), jerami padi mengandung bahan kering $40 \%$, protein kasar 4,30 $\%$, lemak kasar 2,50 \%, serat kasar 33,80\%, bahan ekstrak tanpa nitrogen 35,00\% dengan nilai total zat makanan dapat dicerna sebesar 40,00 \%. Demikian pula dengan jerami jagung, menurut Hartadi dkk (1991), kandungan zat makanan jerami jagung adalah bahan kering $20 \%$, protein kasar 7,00\%, lemak kasar 1,70 \%, serat kasar 33,80 \%, bahan ekstrak tanpa nitrogen 48,60\% dengan nilai total zat makanan dapat dicerna sebesar 52,00\%, sedikit lebih baik dibandingkan jerami padi.

Bahan pakan sumber energi dan protein yang dapat dimanfaatkan di sekitar wilayah Desa Kondangjajar Kecamatan Cijulang Pangandaran diantaranya adalah dedak padi sebagai hasil samping (by-products) industri pengolahan padi dan bungkil kelapa kopra. Menurut Adnyana dan Haryanto (2009), optimalisasi usaha tani dapat dilakukan 
melalui sistem integrasi tanaman dan ternak yang mampu menjamin kelangsungan siklus unsur hara secara sempurna dengan produktivitas yang lebih tinggi, baik dari produksi tanaman maupun produksi ternak. Dedak padi relatif lebih baik dibandingkan dengan jerami padi, dan umumnya digunakan sebagai sumber energi didalam ransum. Menurut Hartadi dkk (1991), kandungan zat makanan dedak padi terdiri dari bahan kering $86,00 \%$, protein kasar $13,80 \%$, lemak kasar $14,10 \%$, serat kasar $11,60 \%$, bahan ekstrak tanpa nitrogen 48,70 \%, dan jumlah total zat makanan dapat dicerna sebesar 74,00 \% dengan kandungan energi metabolis sebesar 2.860 k.kal/kg. Sedangkan bungkil kelapa kopra mengandung $86,00 \%$, protein kasar 21,60 \%, lemak kasar 10,20\%, serat kasar 12,10\%, bahan ekstrak tanpa nitrogen $49,70 \%$, dan jumlah total zat makanan dapat dicerna sebesar 73,00 \% dengan kandungan energi metabolis sebesar $3.330 \mathrm{k} . \mathrm{kal} / \mathrm{kg}$.

Sub sektor peternakan, khususnya peternakan sapi potong masih merupakan bagian penting bagi pertumbuhan ekonomi pada Kelompok Tani Ternak Sapi Potong Putra Nusa di Desa Kondangjajar Kecamatan Cijulang Pangandaran, oleh karena itu keberlanjutan kegiatan sub sektor peternakan ini membutuhkan lembaga penunjang yang relevan. Lembaga pertanian pemerintah yang bertugas membantu memecahkan permasalahan peternak sapi potong di daerah ini adalah Dinas Peternakan melalui penyelenggaraan berbagai kegiatan penyuluhan dan pelatihan sebagai tugas utamanya, serta program pemerintah daerah atau pusat terkait upaya peningkatan produksi pertanian, khususnya produksi sapi potong di daerah tersebut.
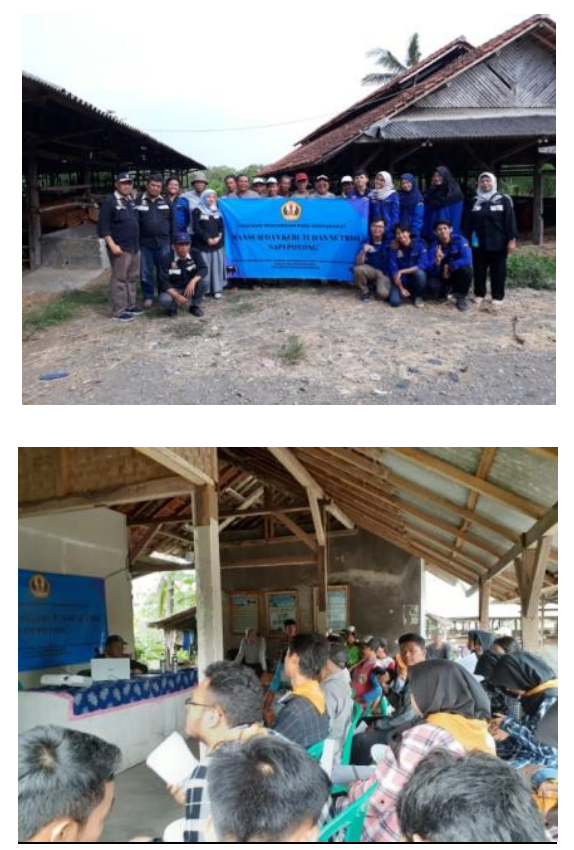

Gambar 1. Pelaksanaan Kegiatan PKM d Kelompok Tani Ternak Sapi Potong Putra Nusa di desa Kondangjajar kecamatan Cijulang Pangandaran (Sumber : Dokumen Kegiatan, 2019)

Pengembangan peternakan sapi potong pada Kelompok Tani Ternak Sapi Potong Putra Nusa di Desa Kondangjajar Kecamatan Cijulang Pangandaran memiliki peluang yang baik karena wilayah Kabupaten Pangandaran merupakan daerah tujuan wisata yang banyak dikunjungi. Berdasarkan aspek sosial dan ekonomi, Kabupaten Pangandaran merupakan daerah baru yang sedang berkembang dari sisi pertambahan jumlah penduduk dan kegiatan ekonomi yang mengakibatkan terjadinya lalulintas orang yang cukup padat, sehingga kebutuhan bahan pangan di daerah tersebut akan semakin tinggi. Dengan demikian, produksi ternak sapi potong pada Kelompok Tani Ternak Sapi Potong Putra Nusa di Desa Kondangjajar Kecamatan Cijulang Pangandaran perlu ditingkatkan kapasitasnya dari kondisi saat ini, baik populasi maupun kapasitas produksinya, supaya dapat memenuhi kebutuhan bahan pangan asal hewan, khususnya daging sapi. Peluang penjualan produk daging sapi di daerah ini relatif tinggi karena perkembangan tingkat pendidikan dan kemampuan ekonomi masyarakatnya serta posisi Kabupaten Pangandaran sebagai daerah tujuan wisata di Jawa Barat.

Populasi sapi potong pada Kelompok Tani Ternak Sapi Potong Putra Nusa di Desa Kondangjajar Kecamatan Cijulang Pangandaran pada tahun 2019 adalah 86 ekor terdiri atas sapi induk 56 ekor, sapi ekor betina muda 14 ekor, sapi jantan muda 3 ekor, anak sapi jantan 4 ekor dan anak sapi betina 4 ekor. Dukungan kearah peningkatan skala usaha ternak sapi potong perlu ditingkatkan lebih jauh karena peluang peningkatan produksi ternak sapi potong masih dapat dilakukan jika usaha ternak yang dilakukan terintegrasi didalam sistem usaha tani yang sedang dijalankan, karena ada beberapa hasil samping (by-products) komoditas tanaman pangan yang dapat dimanfaatkan sebagai sumber bahan pakan untuk pengembangan populasi dan produksi sapi potong diantaranya adalah jerami padi, jerami jagung dan hasil samping dan industri pengolahan tanaman kelapa kopra.

Keunggulan komparatif yang dimiliki oleh peternak sapi potong anggota kelompok berupa potensi pemasaran produk pangan sumber protein, khususnya daging sapi karena posisinya sebagai daerah yang sedang berkembang dan daerah tujuan 
wisata di Jawa Barat akan menjadi dorongan upaya peningkatan populasi dan produktifitas sapi potong di daerah tersebut. Namun demikian, upaya peningkatan skala usaha peternakan sapi potong di daerah tersebut menghadapi beberapa kendala, diantaranya adalah penyediaan bahan pakan berkualitas baik untuk penyusunan ransum sapi potong yang dapat memenuhi kebutuhan zat makanan sapi tersebut sesuai tujuan pemeliharaannya. Untuk mengatasi kendala penyediaan bahan pakan sebagai komponen ransum sapi potong perlu dicari berbagai jenis bahan pakan alternatif yang dapat mengatasinya, diantaranya adalah memanfaatkan bahan pakan lokal, melakukan integrasi antara usaha ternak sapi potong dengan komoditas pertanian lainnya sehingga dicapai sinergi diantara komoditas pertanian tersebut.

Penyediaan bahan pakan yang terdistribusi sepanjang tahun seringkali menjadi kendala dalam sistem pemberian makanan pada sapi potong. Salah satu model yang dapat dikembangkan untuk mendukung peningkatan produksi tanaman pangan dan peternakan secara bersamaan pada satuan luas lahan yang sama adalah menggabungkan kedua komoditas usaha tani ini dalam bentuk sistem integrasi tanaman - ternak (SITT). SITT merupakan sistem usaha tani terpadu, menurut Paat dan Taulau (2009), sistem usahatani terpadu merupakan pilihan yang tepat untuk daerah tertentu seperti Pangandaran, karena daerah Pangandaran memiliki areal lahan sawah dan kebun kelapa kopra yang luas, sebagai contoh dikemukakan oleh Haloho, dkk (2009), bahwa introduksi ternak sapi pada sistem pertanian tanaman padi telah berhasil meningkatkan produktifitas tanaman, sekaligus menambah sumberdaya yang dimiliki petani berupa ternak sapi. Pemeliharaan ternak sapi menghasilkan pupuk kandang dan urin yang berguna untuk menyuburkan lahan pertanian padi atau kebun kelapa kopra, mengurangi penggunaan pupuk kimia yang berarti penghematan biaya dan menjaga kelestarian lingkungan, dan menghasilkan daging sapi untuk kebutuhan masyarakat. Prawirodigdo (2009) menyatakan bahwa terdapat peluang besar dalam penerapan sistem integrasi tenaman kopi dengan ternak ruminan, dalam sistem integrasi ini, tanaman kopi menyediakan kulit kopi untuk komponen pakan ruminan, sedangkan ternak ruminan memproduksi residu dari dekomposisi pakan dalam bentuk feses dan urin sebagai materi setengah jadi yang dapat diproses secara cepat menjadi pupuk organik untuk tanaman kopi.

\section{Hasil Yang Dicapai Pada Kegiatan Penyuluhan.}

Kegiatan penyuluhan mengenai Bahan Pakan Sapi potong telah dilaksanakan pada Kelompok Tani Ternak Sapi Potong Putra Nusa di Desa Kondangjajar Kecamatan Cijulang Pangandaran. Materi yang didiskusikan pada kegiatan penyuluhan terdiri dari tiga bagian utama, yaitu (1) pengenalan bahan pakan (2) kandungan zat makanan pada bahan pakan, dan (3) tatalaksana pemberian ransum sapi potong.

Peserta kegiatan pengabdian kepada masyarakat dalam bentuk pelatihan mengenai Bahan Pakan Sapi Potong yang berpartisipasi aktif adalah pengurus dan anggota kelompok. Partisipasi aktif peserta kegiatan pengabdian kepada masyarakat dalam bentuk kegiatan penyuluhan terlihat pada sesi diskusi dengan dikemukakannya berbagai pertanyaan dan pendapat yang berkaitan dengan materi penyuluhan yang disampaikan, dibandingkan dengan kondisi usaha ternak sapi potong yang sedang dijalankannya.

Pengetahuan peternak anggota Kelompok Tani Ternak Sapi Potong Putra Nusa di Desa Kondangjajar Kecamatan Cijulang Pangandaran mengenai bahan pakan untuk ransum sapi potong mengalami peningkatan setelah mengikuti kegiatan penyuluhan yang diselenggarakan melalui program pengabdian kepada masyarakat. Berdasarkan hasil pre dan post test yang dilakukan terhadap anggota Kelompok Tani Ternak Sapi Potong Putra Nusa di Desa Kondangjajar Kecamatan Cijulang Pangandaran sebelum dan sesudah melakukan kegiatan pelatihan mengenai Bahan Pakan Sapi Potong dapat diketahui bahwa pengetahuan peserta pelatihan mengenai bahan pakan sapi potong mengalami perubahan, yaitu sebelum melakukan pelatihan (pre test) jumlah jawaban benar bervariasi dari $15 \%$ sampai $75 \%$ dengan nilai rataan sebesar $37,27 \%$ dan setelah pelatihan (post test) dihasilkan jumlah jawaban yang benar dengan variasi antara 10 $\%$ sampai dengan $100 \%$ dan nilai rataan yang diperolah sebesar 49,61\%, atau terjadi peningkatan pengetahuan mengenai bahan pakan sapi potong sebesar $12,34 \%$. Perubahan ilmu pengetahuan ini, relatif masih sangat kecil dengan variasi yang sangat tinggi, kondisi ini diduga terjadi karena tingkat pendidikan formal peserta pelatihan yang sangat beragam, sehingga kegiatan pengabdian kepada masyarakat seperti ini perlu dilakukan secara sistematis, berkesinambangan dan berkelanjutan agar penguasaan ilmu pengetahuan dan teknologi 
peternakan, khususnya mengenai pemberian ransum semakin dikuasai oleh masyarakat peternak sapi potong, terutama anggota Kelompok Tani Ternak Sapi Potong Putra Nusa di Desa Kondangjajar Kecamatan Cijulang Pangandaran.

Peningkatan ilmu pengetahuan dan teknologi peternakan bagi masyarakat khususnya peternak sapi potong perlu dilakukan secara terjadwal, berkesinambungan dan berkelanjutan, sehingga adopsi inovasi teknologi peternakan dapat berlangsung sesuai perkembangan kegiatan peternakan dan potensi sumber daya alam yang tersedia pada Kelompok Tani Ternak Sapi Potong Putra Nusa di Desa Kondangjajar Kecamatan Cijulang Pangandaran, dan pada gilirannya dapat dikelola dan dikembangkan untuk kepentingan peningkatan kesejahteraan peternak sapi potong yang terlibat didalam kegiatan tersebut. Menurut Yunasaf dkk (2011), tingkat pendidikan dan pengetahuan masyarakat petani yang rendah dapat mengakibatkan penerimaan dan pelaksanaan terhadap suatu inovasi menjadi kurang baik. Namun demikian, tingkat pendidikan dan pengetahuan masyarakat dapat ditingkatkan melalui metode pendidikan informal diantaranya melalui kegiatan penyuluhan yang diselenggarakan sesuai kebutuhan dan tingkat pendidikan serta pengetahuan masyarakat sasaran.

Implementasi pengembangan peternakan sapi potong dengan penyediaan ransum berbasis bahan pakan lokal yang tersedia dan disajikan dalam bentuk ransum lengkap membutuhkan program penyuluhan dan pelatihan yang lebih lanjut dan sistematis, karena berbagai pertimbangan seperti harga dan ketersediaan bahan baku lokal untuk menyusun ransum bagi pengembangan peternakan sapi potong, skala usaha ternak sapi potong yang sedang dilakukan, dan kebijakan pengembangan peternakan yang ditetapkan oleh pemerintah daerah, khususnya Pemerintah Kabupaten Pangandaran.

\section{Kesimpulan}

Pengetahuan anggota kelompok mengenai bahan pakan sapi potong dalam rangka pengembangan ternak sapi potong telah mengalami perubahan dan peningkatan, sebesar 12,34\%. Kegiatan pengabdian kepada masyarakat yang telah dilaksanakan dapat membantu percepatan penyampaian informasi antara peternak dengan pihak terkait yang memiliki kepentingan terhadap pengembangan ternak sapi potong di Desa
Kondangjajar Kecamatan Cijulang Pangandaran dan sekitarnya.

\section{Daftar Pustaka}

Adnyana, M.O dan B. Haryanto, 2009. Pengembangan kelembagaan jaringan Litkaji sistem integrasi tanaman-ternak. Lokakarya Nasional Pengembangan Jejaring Litkaji Sistem Integrasi Tanaman - Ternak, PUSLITBANGNAK dan BPPT, Bogor.

Catur, T.B., J. Purwanto., F.R Uchyani., dan A.S. Wuri. 2010. Dampak Alih Fungsi Lahan Pertanian Ke Sektor Non Pertanian Terhadap Ketersediaan Beras Di Kabupaten Klaten Provinsi Jawa Tengah. Caraka Tani. 25 (1), 38-42.

Corre, M.D., G. Dechert., and E. Veldkamp. 2006. Soil Nitrogen Cycling following Montane Forest Conversion in Central Sulawesi, Indonesia. Proquest Agriculture Journal. 70 (2) : 359-366.

Haloho L., P. Yufdi, dan T. Sembiring, 2009. Potensi Pengembangan Ternak Sapi Mendukung Peningkatan Produktifitas Padi di Desa Lubuk Bayas Kecamatan Perbaungan, Kabupaten Serdang Begadai. Lokakarya Nasional Pengembangan Jejaring Litkaji Sistem Integrasi Tanaman - Ternak, PUSLITBANGNAK dan BPPT, Bogor.

Hartadi, H., S. Reksohadiprodjo, dan A.D. Tillman. 1991. Tabel Komposisi Pakan Untuk Indonesia. Gadjah Mada University Press. Yogyakarta.

Hiroyuki, A., T. Tatsumi, and K. Hidesato. 2002. Conservation Of Agricultural Land Resources Through Extensive Management. Jurnal Rural And Environmental Engineering, 42 (2), p: 44-59.

Irawan, B dan S. Friyatno. 2002. Dampak Konversi Lahan Sawah Di Jawa Terhadap Produksi Beras Dan Kebijakan Pengendaliannya. SOCA (SocioEconomic Of Agriculturre And Agribusiness. 2 (2), 1-33.

Paat, C. P., dan L. A. Taulu. 2009. Potensi dan peluang pengembangan sistem integrasi Jagung - Padi di Sulawesi Utara. Lokakarya Nasional Pengembangan Jejaring Litkaji Sistem Integrasi Tanaman - Ternak, PUSLITBANGNAK dan BPPT, Bogor.

Prawirodigdo, S. 2009. Peluang mendayagunakan kulit kopi sebagai bahan pakan dalam sistem integrasi tanaman - ternak ruminansia. Lokakarya Nasional Pengembangan Jejaring Litkaji Sistem Integrasi Tanaman - Ternak, PUSLITBANGNAK dan BPPT, Bogor.

Saputra, I.G.S.W. dan M.K.S. Budhi. 2015. Studi alih fungsi lahan dan dampaknya terhadap sosial ekonomi petani jambu mete di kecamatan Kubu 
Dhalika et al (2021) FJCS 02(1): 7 - 14

kabupaten Karangasem. E-Jurnal Ekonomi dan Bisnis Universitas Udayana. 4.08 ; 555 - 570.

Yunasaf, U., C. Gunadi., N. Setiawan. 2011. Hubungan karakteristik inovasi, peran penyuluh dengan tingkat penerapan inovasi teknologi pemanfaatan hijauan pakan. Prosiding Seminar Nasional Peternakan Berkelanjutan Ke-3. Fakultas Peternakan Universitas Padjadjaran, Sumedang. Halaman 445 - 450. 